\title{
The value of Admiral Matelieff's writings for studying the history of Southeast Asia, c.1600-1620
}

\author{
Peter Borschberg
}

\begin{abstract}
Cornelis Matelieff de Jonge (also Cornelis Cornelisz. Matelief) was a director of the Dutch East India Company (VOC) and fleet commander of a voyage to the East Indies in 1605-08. On his return to the Dutch Republic in September 1608, he wrote a series of epistolary memorials, or 'discourses', in which he recommended sweeping reforms in the way in which the VOC conducted business in Asia. Not only did these recommendations serve as a blueprint for subsequent developments of the VOC during the early seventeenth century, the documents also made astute observations about the dynamics of trade, geopolitics, agency of the Asian rulers as well as political power on the Malay Peninsula, Java, Maluku and Borneo. This article problematises these primary sources and demonstrates how they can be profitably mined for the history of trade and diplomacy of early seventeenth century Southeast Asia.
\end{abstract}

Researchers of early modern Southeast Asia will take interest in the hitherto neglected writings of Cornelis Matelieff (sometimes Cornelis Cornelisz. Matelief, c.1570-1632). He served as a director of the Rotterdam Chamber of the Dutch East India Company (Veerenigde Oost-Indische Compagnie, VOC), and immediately before and after his voyage to Asia (1605-08) also on the central board of directors known as the Gentlemen Seventeen. As a fleet commander, Matelieff received instructions that staked out commercial and military objectives: he was to attack and seize Melaka (Malacca) from the Portuguese, lend assistance to Dutch military operations in Maluku (Moluccas), and secure privileges for the VOC to trade with Ming China. On his return to the Netherlands in September 1608, the admiral penned a series of epistolary memorials, which he circulated among the VOC directors, as well as leading figures of the Dutch Republic's political establishment. He encouraged the recipients of his writings (among whom were the young Hugo Grotius and the senior political leader Johan van Oldenbarnevelt) to embark on a programme of institutional and operational reform that would transform the way the VOC organised its voyages

Peter Borschberg is an Associate Professor in the Department of History at the National University of Singapore. Correspondence in connection with this article should be addressed to: hispb@nus.edu.sg. At the time of completing this article the author was a Visiting Professor at the Asia-Europe Institute, University of Malaya. Research contained herein has been sponsored by the international training and research group 'Baltic Borderlands' (IRTG 1540) based at the University of Greifswald and funded by the German Research Foundation (DFG). A special mention goes to the 'Singapore History Anthology Project' (R-110-000-052-112). 
and conducted business across Asia. Matelieff's writings also contain invaluable insights on the political and economic state of Southeast Asia in the first two decades of the seventeenth century. ${ }^{1}$

As Matelieff is not a name familiar to many researchers of Southeast Asia, this article will provide a brief sketch of the economic and political environment he was working in, together with a short biography and a synopsis of his voyage to Asia. These comments pave the way for exploring the materials as sources for the commercial and diplomatic history of Southeast Asia as well as of the Dutch presence that evolved against the backdrop of Luso-Dutch rivalry in Asia. One need bear in mind that this was not just about a protracted, globally waged war between two European powers; it was also a story of how the Dutch and the Iberians (the Spanish and Portuguese) positioned themselves vis-à-vis local rulers, and how in turn their diplomatic, strategic and commercial positioning impacted relations not only of the Europeans with various Southeast Asian polities, but also between the Southeast Asian rulers.

Minding the temporal and spatial markers is crucial: attention shall be placed on Southeast Asia during the opening decades of the seventeenth century, but more specifically in the period between the formation of the VOC in 1602 and the founding of Dutch Batavia in 1619.

Matelieff's writings yield informative glimpses into the structures and dynamics of Southeast Asian polities, most significantly with reference to Johor, Banten (Bantam), Jayakerta (Jacatra, today's Jakarta), Banda and Ternate. Additional information can also be found concerning Ayutthaya (Siam), Tenasserim, Patani, Champa, Pulau Pinang (Penang), Kedah, Melaka, Tidore, Makassar, Mindanao and Panay.

Before turning to examine the Southeast Asian polities of Johor, Banten, Jayakerta, Banda and Ternate in detail, it is helpful to say a few words about the protagonist, his career, and his voyage to Asia from 1605 to 1608.

\section{Matelieff's voyage to Asia, 1605-08}

Cornelis Matelieff de Jonge, or Cornelis Junior, ${ }^{2}$ was born around 1570 into a respectable family. His father, Cornelis senior, appears to have married into money. Judging by the style of his writing, Cornelis junior (hereafter simply Matelieff) received a decent, but not an elite education for his time. In his private letters and memorials, he expressed himself in a language that is direct and unadorned. Matelieff was involved with one of the smaller commercial ventures that was merged into the VOC in $1602 .{ }^{3}$ For this reason, he became one of the directors of the VOC's

1 Journal, memorials and letters of Cornelis Matelieff de Jonge: Security, diplomacy and commerce in 17th-century Southeast Asia, ed. Peter Borschberg (Singapore: NUS Press, 2015); hereafter abbreviated as $C M J$.

2 Concerning the life and family background of Admiral Matelieff, see J.G. Frederiks, 'Cornelis Cornelisz Matelieff de Jonge en zijn geslagt', Rotterdamsche Historiebladen, ed. J.H. Scheffer and Fr. D.O. Obreen, 3 afd., 1.1 (1871): 204-357; also the introduction to Machtsstrijd om Malakka: De reis van VOC-admiraal Cornelis Cornelisz. Matelief naar Oost-Azië 1605-1608, ed. Leo Akveld (Zutphen: Walburg Pers, 2013).

3 See also Charles R. Boxer, Jan Compagnie in war and peace, 1602-1799 (Hong Kong and Singapore: Heinemann Asia, 1979); C.R. Boxer, The Dutch seaborne empire, 1600-1800 (London: Hutchinson, 
Rotterdam chamber and by 1604, he served as one of the so-called Gentlemen Seventeen, the company's central board of directors. In May of the following year, Matelieff was appointed fleet commander of the second voyage organised under the flag of the VOC proper. ${ }^{4}$ Equipped at the cost of 2.1 million guilders, the fleet comprising 11 larger ships and over 1,400 men set sail carrying secret instructions that were to be opened at sea. ${ }^{5}$ These commanded an attack on Melaka that would dislodge the Portuguese as its master. ${ }^{6}$

In 1606, the Dutch attacked Melaka with the support of their Malay allies from Johor. The campaign failed for a number of reasons that included the arrival of a powerful armada placed under the command of the Portuguese viceroy, Dom Martim Alfonso de Castro. According to surviving reports, it was the largest armada that the Portuguese had raised in the East Indies to that date.

Following the failed siege of Melaka, Matelieff's ships scattered and called at different ports around Asia. Three ships were placed under the command of Vice-Admiral Olivier de Vivere, headed for Aceh and the Coromandel Coast of India, while the remaining vessels under Matelieff headed for Banten and on to the Spice Islands. Along the coast of northwestern Java, the admiral also made an important stop at the port of Jayakerta, a town with an estimated population of 4,000 inhabitants at the time. It was ruled by Pangeran Wijayakrama (sometimes called Jayawikrama), who was described in Dutch sources of the period as a (tributary) 'vassal' of Banten. ${ }^{7}$ The voyage continued to Ternate, which had recently suffered an attack by the Spanish in 1605-06. Joining forces with their ally Tidore, the Spanish defeated Ternate, made hostage of its ruler Sayed Berakat, together with members of his family, while the remaining members of the Ternatan court fled. The Spanish attack punished the Ternatan ruler for earlier entering into friendly relations with the Dutch. ${ }^{8}$

The Maluku islands were the only centres of clove production at this time. Matelieff struck a deal with the newly installed pubescent ruler in May 1607.

1965); and Femme S. Gaastra, De geschiedenis van de VOC, 4th ed. (Zutphen: Walburg Pers, 2002) or its English translation, The Dutch East India Company: Expansion and decline (Zutphen: Walburg Pers, 2003).

4 A summary of Matelieff's voyage is found in Pieter Anton Tiele, 'De Europeërs in den Maleischen Archipel', pt VII, Bijdragen en Mededelingen van het Koninklijk Instituut voor Taal-, Land- und Volkenkunde 32 (1884): 49-118; and the introduction to Akveld, Machtsstrijd om Malakka.

5 Pieter van Dam, Beschryvinge van de Oostindische Compagnie, ed. Frederik W. Stapel, 8 vols. (The Hague: Martinus Nijhoff, 1931-43), vol. I.1, pp. 163-4, 224.

6 Although copies of these instructions no longer survive, their contents are broadly known. These are alluded to in a petition drafted by Hugo Grotius to the States-General of the Dutch Republic dated 4 March 1606. The original is preserved in the National Archives of the Netherlands, Collectie Hugo de Groot Supplement, fols. 374-9. A discussion of the secret instructions follows on fols. 374 verso-375 recto. It is intimated that Admiral Steven van der Hagen, who had embarked on his voyage to the East Indies in December 1603, was given a set of secret instructions that listed ways of damaging the Iberian enemy on land and at sea. Cornelis Matelieff, the document also clarifies, had been issued the same (or at least very similar) instructions.

7 This ruler is variously named in other sources as Pangerang Jayawikarta or Wijayakama. My thanks to Merle C. Ricklefs for helping resolve the identity of the ruler.

8 Paulo Jorge de Sousa Pinto, The Portuguese and the Straits of Melaka, 1575-1619: Power, trade and diplomacy (Kuala Lumpur: MBRAS; Singapore: NUS Press, 2012), p. 319; Arnold van Wickeren, Geschiedenis van Portugal en van de Portugezen overzee, pt XVI (Heerhugowaard: n.p., 2007), pp. 51-2. 
Because of this agreement, the young ruler Modafar and his council would exclusively commit to the sale of cloves to the VOC, and in return, the Dutch would lend armed protection to Ternate and its royal court against their mutual enemies, specifically the Iberian powers. ${ }^{9}$ In a first move to guarantee the safety of Modafar and his court, Matelieff founded a fort at Malayo (sometimes Malayur or Malayura), garrisoned the new fort with some of his men, and placed two vessels at the disposal of Ternate for coastal defence. Little did Matelieff realise that, shortly after his departure for China, the Spanish would attack his new fort, and destroy the two vessels he had left behind to defend the coast and patrol nearby waters.

The journey continued via Mindanao and the Visayas to the Fujian coast of China. The commercial instructions issued by the Gentlemen Seventeen in May 1605 had urged Matelieff to open the Chinese market to VOC trade. After a futile attempt to strike up commerce at Nan'ao Dao as well as on the island of Lantau in the Pearl River estuary (now part of the Hong Kong SAR), the Dutch resolved to abandon the China leg of their mission and set course for the Malay Peninsula and Java. The admiral dropped anchor on 17 October 1607, off Pulau Cecir (present-day Cù Lao Thu), an island whose residents are reported to have been loyal to the ruler of Champa. In the course of his discussions with local officials, Matelieff came to know about the problems at Champa's royal court on the mainland. ${ }^{10}$

The admiral returned to the port of Banten in the closing weeks of 1607 . While he was still taking on provisions for his homebound journey, three noteworthy developments took place.

First, a fresh set of instructions was received from the Gentlemen Seventeen in December 1607 in which they urged VOC fleet commanders in Asia to temporarily set commercial priorities aside and concentrate on the military objectives of their voyage. This included especially the need to secure Johor for the Dutch company. ${ }^{11}$

Second was the arrival of VOC Admiral Paul van Caerden, the VOC's third fleet commander, who on his outbound journey to Banten had attacked and damaged Portuguese positions in Mozambique (March 1607), seized a Portuguese merchantman off the coast of Goa (October 1607), and also signed a treaty with the Samorin of Calicut. The two commanders, Matelieff and Van Caerden, exchanged letters and held face-to-face conversations at Banten in early January $1608 .{ }^{12}$

The third was the arrival of Siamese King Ekathotsarot's emissaries, ${ }^{13}$ who were brought to Europe aboard Matelieff's flagship. This was the first embassy sent by the

9 The text of the formal treaty signed on 26 May 1607 has been translated in CMJ, pp. 421-4.

10 Concerning developments in Champa in this period, see also C.R. Boxer, 'A Spanish description of the Chams in 1595', in Readings on Asian topics: Papers read at the Inauguration of the Scandinavian Institute of Asian Studies 16-18 September 1968 (Lund: Studentlitteratur, 1970), pp. 35-44. In general, see also Pierre-Yves Manguin, Les Portugais sur les côtes du Viêt-Nam et du Campa: Étude sur les routes maritimes et les relations commerciales, d'après les sources portugaises (XVIème, XVIIème, XVIIIème siècles) (Paris: École Française d'Extrême-Orient, 1972).

11 See De derde reis van de V.O.C. naar Oost-Indië onder het beleid van Admiraal Paulus van Caerden, uitgezeild in 1606, 2 vols., ed. A. de Booy (The Hague: Martinus Nijhoff, 1970), II, p. 121.

12 See also CMJ, pp. 233-50.

13 Paul Pelliot, 'Les Relations du Siam et de la Hollande en 1608', T'oung Pao 32 (1936): 223-9; and J.J.L. Duyvendak, 'The first Siamese embassy to Holland', T'oung Pao 32 (1936): 285-92; 
Siamese to the Dutch Republic and only the third (and last) Southeast Asian embassy to be formally received in Europe before $1800 .{ }^{14}$ After this date, Asian emissaries were received by the VOC governor-general in Batavia.

After completing their three-year journey, the remaining ships of Matelieff's fleet appeared off the coast of the Netherlands and arrived at the beginning of September, 1608.

Following this summary of Matelieff's voyage to the East Indies, some brief comments are warranted about the nature of the extant manuscript documentation and the printed sources.

\section{Matelieff's travelogue}

Accounts have been printed since the seventeenth century that recount different facets of Matelieff's voyage to the East Indies. They also evidence the lessons learnt from fighting the Portuguese in the East Indies, negotiating with Southeast Asian rulers, optimising departure times, as well as maintaining discipline aboard VOC ships. Perhaps the best-known document is the travelogue touching on Matelieff's voyage, commonly known by the short title Journael ende Historische Verhael (Journal and historical narrative), or just simply Journael. ${ }^{15}$ Although the text was circulating in manuscript form after 1608, it was only about four decades later that it appeared in print. The first edition of the text forms part of Isaac Commelin's printed collection of Dutch voyages to the East Indies (1645-46). ${ }^{16}$ One manuscript copy of uncertain dating, preserved in the Maritime Museum in Rotterdam, has been published in the travel series of the Linschoten Vereeniging (Linschoten Society). ${ }^{17}$ One should bear in mind that this travelogue was most probably not finalised by Matelieff himself, but rather by one, or more likely both, of his personal secretaries, Abraham van den Broeck and Jacques l'Hermite de Jonge. The Journael also features other types of materials that have been inserted into the main text, including letters, treaties, as well as some lengthy passages excerpted from other unidentified sources.

P. Borschberg, The Singapore and Melaka Straits: Violence, security and diplomacy in the 17th century (Singapore: NUS Press; Leiden: KITLV, 2010), pp. 93-4.

14 Concerning this Siamese diplomatic mission, its political and commercial context, as well as longerterm repercussions for the commercial and military strategy of the VOC, see P. Borschberg, 'Cornelis Matelieff, Hugo Grotius, and the King of Siam (1605-16)', Modern Asian Studies, forthcoming, 2018.

15 The full title of the first self-standing edition of the texts published in 1648 reads: Journael, Ende Historische Verhael / van de treffelijcke Reyse / gedaen naer Oost-Indien, ende China, met elf Schepen. Door den Manhaften Admirael Cornelis Matelief de Jonge. Uyt-ghevaren in den Jarae 1605. En wat haer in de volghende Jaren 1606, 1607, ende 1608 weder-varen is. Een seer Vreemde en Wonderlijcke Reyse [Journal and historical narrative of the excellent voyage made to the East Indies, and China, with eleven ships. By the manly Admiral Cornelis Matelief de Jonge, who sailed out in the year 1605 . What they experienced in the subsequent years 1606, 1607 and 1608. A very strange and wonderful voyage.]

16 Isaac Commelin, Begin ende Voortgang vande Vereenigde Neerlandsche Geoctroyeerde Oost-Indische Compagnie, 4 vols., facsimile in 2 vols. (Amsterdam: Facsimile Uitgaven Nederland, 1969 [1646]). The account of Matelieff's voyage appears in vol. II of the 1645/6 original and in vol. III of the 1969 facsimile edition. The Journael was first published as a self-standing text in 1648. For the title page, see the illustration in $C M J$, p. 105.

17 Rotterdam, Maritiem Museum, Collectie W.A. Engelbrecht, no. 900; Akveld, Machtsstrijd om Malakka. 


\section{Memorials and letters}

In addition to the Journael are several documents that were mostly written after the admiral returned to the Netherlands. In scholarship touching on the voyage of Matelieff to the East Indies, these are referred to in Dutch-language studies as 'discourses' ${ }^{18}$ They represent epistolary memorials addressed to key members in government and in the VOC in which the admiral spelled out recommendations for improving operations in Asia, enhancing the security of company assets as well as the interests of Dutch allies against the Iberian powers. Manuscript copies of these memorials (with the notable exception of the one written around June 1607) are found among the working papers of the Land's Advocate of Holland, Johan van Oldenbarnevelt, as well as those of Hugo Grotius, who at the time was serving in various capacities both for the city of Rotterdam as well as the province of Holland. Grotius's unpublished treatises, notes and working papers remained in the family until 1864, when they were sold at a public auction in November that year. ${ }^{19}$ Most of these papers eventually found their way into public collections, and many of the documents touching on East Indian affairs can now be consulted either in the Dutch National Archives in The Hague or also in the Gemeentearchief (Municipal Archives) in Rotterdam. ${ }^{20}$ The memorials are of particular interest as they yield insights into the strategic and commercial thought of Matelieff, the early geo-political deliberations of the Gentlemen Seventeen, as well as the commercial and strategic priorities of the Dutch Republic's political leaders in relation to Asia.

Why did the admiral write his memorials, and what do we know about his motivations? Matelieff was concerned to build the long-term future of the VOC against several limitations and personal interests that notably included the constraints resulting from the VOC's so-called ten-year account, ${ }^{21}$ as well as the directors' short-term profit-oriented thinking. ${ }^{22}$ Many of the suggestions he advanced concerned the improvement of operational efficiency, such as the creation of an intra-Asian fleet, the founding of a rendezvous (central base) in Asia or the better timing of departures and return voyages. His memorials aimed to balance the company's twin role as an agent of commerce and of war, and in so doing, the admiral devised a blueprint for future Dutch activities across the Indonesian Archipelago and Asia at large.

How should one assess the value of these writings for the early seventeenthcentury history of Southeast Asia? The answer will follow in two parts. The first will assess the value of Matelieff's writings with reference to the Dutch presence

18 See R. Bijlsma, 'De discoursen van Cornelis Matelieff de Jonge over den Staat van Oost-Indië', Nederlandsch Archievenblad 35 (1927-28): 49-53; full transcripts of the original Dutch-language memorials are found in Frederiks, 'Cornelis Cornelisz Matelieff de Jonge en zijn geslagt'.

19 See Catalogue des Manuscrits Autographes de Hugo Grotius. Vente à La Haye, 15 Novembre 1864, sous la direction et au domicile de Martinus Nijhoff (The Hague: Martinus Nijhoff, 1864).

20 The Hague, Nationaal Archief van Nederland (hereafter NAN), 3.01.14, Collectie Johan van Oldenvarnevelt; NAN, 1.10.35.02, no. 40, Collectie Hugo de Groot, Supplement; Rotterdam, Gemeentearchief, Ms. 33.01, no. 3366-7.

21 After ten years, VOC shareholders were entitled to cancel their shares and withdraw their capital, as opposed to selling the shares on the bourse at market price. Withdrawing capital from the company was not seen to be conducive to making long-term investments and planning.

22 On this point see also P.J.A.N. van Rietbergen, De VOC 1602-1795; 's werelds eerste multinational tussens commercie en cultuur (Amersfoort-Brugge: Bekking \& Blitz, 2012), p. 35. 
and early colonial expansion in insular and peninsular Southeast Asia. The second will address the value of these writings for understanding the nature of regional trade, the dynamics between the different Malay polities, as well as certain factions within Johor.

One must also bear in mind that the proposals to monopolise the sources of nutmeg, mace and cloves (which will be addressed in the following section) were advanced with an eye on fixing European and Asian competitors and securing a more reliable supply of spices, rather than in establishing a colonial empire, strictly speaking. In fact, Matelieff's proposal to co-opt the ruler of Makassar and install him as the new ruler of the Banda Islands is evidence that he was not scheming for direct control and imperial expansion: he even admitted that the Dutch had no experience in ruling 'Muslim subjects'. ${ }^{23}$

\section{Matelieff's proposal to monopolise nutmeg, mace and cloves at source}

Historians of the VOC, especially in the Netherlands, have occasionally described Matelieff as an early architect of the first Dutch Empire in Asia. This conclusion is drawn based on the proposals staked out in the memorials to change the way the company did business in Asia. In his study The Dutch East India Company, Femme Gaastra underscored:

In this [rethinking their strategy Asia] the Gentlemen XVII followed the ideas of Cornelis Matelief, who had again taken up a place in the Rotterdam board of directors after returning from Asia. Matelief set out his ideas about the policies the VOC should follow in Asia in a series of four papers written in 1608 and 1609 and showed himself here as the first person in the directorate of the Company to think in terms of empire building. ${ }^{24}$

It is unclear whether the recommendations expounded in the memorials were all (or at least predominantly) Matelieff's own, whether they had been raised and discussed during meetings of the VOC's directors, or whether they had originated in government circles. A combination of these is also within the realm of possibilities.

Matelieff recommended heavily investing in commercial and military infrastructure, the founding of settlements, and the construction of fortifications. This infrastructure was to be supported by military alliances with local rulers who were favourably disposed toward the Dutch and openly hostile toward the Iberian powers. ${ }^{25} \mathrm{~A}$ principal consideration behind these recommendations was the on-going globally fought conflict (the Revolt of the Netherlands or Eighty Years War) between the Dutch Republic and the Spanish Empire (together with its dynastic allies, especially Portugal). In addition to securing operations within the territories covered by the VOC's charter, the aim was to protect allies against the Spanish and the Portuguese in return for sharing the spoils of war and in securing exclusive delivery contracts with Asian rulers. Matelieff's treaties with the kings of Johor (1606) and

23 CMJ, pp. 338, 348.

24 Gaastra, The Dutch East India Company, pp. 39-40.

25 See also P. Borschberg, 'Left "holding the bag": The Johor-VOC alliance and the Twelve Years Truce (1606-1609)', in The Twelve Years Truce (1609): Peace, truce, war and law in the Low Countries at the turn of the seventeenth century, ed. Randall Lesaffer (Leiden: Brill-Nijhoff, 2014), pp. 89-120. 
Ternate (1607), as well as Vice-Admiral Olivier de Vivere's agreement with Aceh (1607) offer instructive examples in this regard. ${ }^{26}$

Linking to the policy of forging alliances with local rulers, the admiral recommended the creation of monopolies in the production and delivery of key spices. Such a move was first mooted in a letter addressed to the directors in June $1607 .^{27}$ This letter divided Asian trade into six main branches, three of which relate to specific commodities: pepper, cloves, and nutmeg (together with its by-product, mace). The remaining three branches are geographical: Cambay, the Bay of Bengal (Coromandel, Bengal) as well as China. Japan was mentioned as an appendage of the Chinese market. Matelieff strongly recommended that supplies and delivery of nutmeg, mace and cloves be monopolised at source.

Some additional background information is needed to better appreciate the context in which the admiral advanced such a proposal. In his Itinerario and Reygeschrift (published in 1595-96), the Dutchman Jan Huyghen van Linschoten asserted that one could 'fill the world with cloves' harvested on the islands of Maluku. ${ }^{28}$ Such a claim was obviously intended to fuel the imagination in Europe of just how much profit could be reaped from the clove trade. Linschoten had based his claims on secondhand reports, and in any case, he himself had never set foot on the Spice Islands. Less than two decades later, the English merchant John Saris - better known to historians today for his landmark visit to Japan - appraised the aggregate clove production at 3,975 Maluku bahar of about $273 \mathrm{~kg}$ each. ${ }^{29}$ This would estimate total production at about 1,197 metric tons. One can also place an approximate market value to this harvest. Extant documentation informs that the Dutch and English purchased the cloves at 50 Spanish ryals-of-eight per Maluku bahar. ${ }^{30}$ Using this price as a guideline, the total harvest would be worth the equivalent of about 5.34 metric tons of coin-grade silver.

Just a few years later, in 1615, Matelieff estimated the clove harvest on all the islands of Maluku at 1,500 bahar. When one applies the same prices to calculate the market value in coin-grade silver, the figure would amount to just over 2 metric tons.

When comparing the estimates of Saris and Matelieff with earlier statements by Van Linschoten relating to the size and value of the Maluku clove harvest, it is clear that production fluctuated considerably during the opening years of the seventeenth century. Civil unrest, disturbances, and armed European intervention triggered a steep decline in production at the beginning of the seventeenth century. As one source would have it, there were simply not enough people left on the islands to bring in the clove harvest, with the result that a good part of it was left rotting on the ground.

26 For English translations of these contracts, see CMJ, pp. 158-60 (treaties with Johor), as well as supplementary documents II (treaty with Aceh), pp. 397-400, and IV (treaty with Ternate), pp. 421-4.

27 CMJ, pp. 335-43.

28 Jan Huyghen van Linschoten, Itinerario. Voyage ofte Schipvaert van Jan Huygen van Linschoten naer Oost ofte Portugaels Indien, 1579-1592, and Reys-geschrift vande navigatiën der Portugaloysers, ed. Hendrik Kern and J.C.M. Warnsinck, 2nd ed., 5 vols. (The Hague: Martinus Nijhoff, 1939).

29 The voyage of Captain John Saris to Japan, 1613, ed. E.M. Satow (London: Hakluyt Society, 1900), pp. 58-9.

30 Ibid., p. 58. 
There are no reliable estimates for the nutmeg harvest for these years, but similar observations can be made for the Bandas as for the Maluku Islands. At the time, nutmeg and mace grew only on the Bandas. In view of the wars and civil unrest at the dawn of the seventeenth century, it is only reasonable to assume that the harvest of nutmeg and mace would have been more modest, probably less than half of the clove harvest, or somewhere in the region of between 400-600 metric tons. The mace harvest would have been smaller still, at least measured by weight.

Returning to Matelieff's proposal(s) to monopolise the supply of nutmeg, mace and cloves, the admiral recommended starting with nutmeg and mace. Given the very limited number of islands on the Bandas where nutmeg and mace grew, and given the limited size of the aggregate harvest, the proposed monopolisation of supplies at source seemed both realistic and feasible.

In his memorial of June 1607 Matelieff also suggested the monopolisation of cloves from Maluku. He cautioned, however, that this would be more challenging than monopolising the supply of nutmeg and mace, and underscored that success depended on severing Iberian supply lines to Maluku from Manila and Goa. With hindsight, these recommended steps have an almost prophetic ring, for this was precisely how the VOC would proceed after 1609, starting with the monopolisation of nutmeg and mace on the Bandas.

In sharp contrast to monopolising nutmeg, mace and cloves, Matelieff advised against attempting the same with pepper. This was because the aggregate Southeast Asian pepper harvest - unlike cloves, nutmeg and mace - was said to have about doubled within the period 1595 to 1610. Matelieff estimated that more than half the value of all the spices transacted by the VOC in the East Indies was in pepper. He readily conceded: 'I cannot say with certainty now in what quantity; there is always enough pepper in the Indies.' 31 Banten, which was by far the largest single marketplace for pepper, was set to export 200,000 bags weighing 56 Amsterdam pounds each. ${ }^{32}$ That amounted to a total of about 5,260 metric tons of pepper. When taking a book value of around 14 ryals-of-eight per bahar of 3 pikul (about $180 \mathrm{~kg}$ ) - this was in fact the approximate price used to value the VOC's pepper stock in Johor in $1613-14^{33}$ - then the Banten exports amounted to a value of about 270,000 ryals-of-eight or the equivalent of about 7.83 metric tons of coin-grade silver. At this point in time Banten's pepper exports alone would have been broadly equivalent to the estimated value at source of the clove, nutmeg and mace harvests combined.

Matelieff observed that ample pepper could be obtained not only at Banten, but also at Palembang, Jambi, Indragiri, Kampar, Johor, Patani, Kedah, and Aceh. This is not the list of the pepper markets according to their size or significance, but rather according to their geographic location from south to north. Many, if not most, of the transactions in this spice were not handled by the Europeans, but (as the Portuguese medic Garcia da Orta had already observed) were being exported to

31 CMJ, pp. 318-19.

32 Ibid., pp. 363, 369.

33 This price derives from a report by Adriaen van der Dussen dated 10 Nov. 1614, in Bouwstoffen voor de Geschiedenis der Nederlanders in den Maleischen Archipel, ed. Pieter Anton Tiele and Jan Ernst Heeres, 3 vols. (The Hague: Martinus Nijhoff, 1886-95), I, pp. 70-79. 
China, Martaban, Pegu, as well as to Arabia and the Red Sea region. 'Much will be taken westward by the Muslims,' da Orta duly underscored. ${ }^{34}$

How was one then to deal with the pepper market according to the admiral's memorial of June 1607? The answer has a surprisingly contemporary ring: by flooding the European market with pepper, a move that in the present day would be labelled product dumping. Matelieff thought it futile to try to seek a monopolisation of the Southeast Asian pepper trade, as there was an ever-growing supply that, as far as one could see, always outstripped demand..$^{35}$ Instead of cornering supplies (as advised in the case of cloves, nutmeg or mace) and thus tying up too much of the company's working capital in pepper stocks, the aim here would be to target competitors like the Portuguese and the English East India Company. The objective would be to create a glut of pepper in Europe. The admiral strongly advised that the VOC treat pepper destined for Europe as ship's ballast and cautioned not to expect any profit from disposing of it on arrival. As a consequence of forfeiting profits on pepper - at least temporarily - the VOC would have to explore additional channels for generating income either from trade or privateering. ${ }^{36}$

\section{Selecting a permanent base in Asia}

After examining Matelieff's proposals for nutmeg, mace, cloves and pepper, the discussion now turns to examine another key proposal found in his memorials: establishing a so-called rendezvous, or a permanent base, in (Southeast) Asia. The proposal was also deemed to be most urgent from among the admiral's recommended changes. He explained:

First of all, we must choose a rendezvous or meeting place in the Indies, where all ships from these lands can easily call and take in fresh supplies. All provisions, foodstuffs and ammunition of war should also be brought there and amassed gradually, for in the Indies it is impossible to obtain these quickly. This has not been attempted at all thus far, although it is what we need most in the East Indies. All goods from all regions could also be brought and kept safely there, for inland navigation with large ships involves a lot of expenses and inconvenience. ${ }^{37}$

The reasons for establishing a rendezvous are clear: Once Dutch fleets arrived in Asia it was not always possible to obtain supplies of spices on the spot in sufficient quantities to fill the cargo holds of the VOC's blue-water ships. As a result, fleet commanders and crews wasted too much time waiting for the next spice harvest (or at least for more supplies) to come in from other production areas. Matelieff thought all of this waiting to be a very inefficient way of doing business, especially since the so-called maandgelden (monthly salaries) paid to company servants had to be given whether or not the men were working (productively). ${ }^{38}$ For this reason, he thought it preferable to have persons stationed on-site who would organise the

34 Garcia da Orta, Colloquies on the simples and drugs of India, trans. C. Mackham (Delhi: Sri Satguru, 1987) pp. 367-8; citation from p. 368.

35 CMJ, p. 319.

36 Ibid., p. 337.

37 Ibid., p. 255.

38 Ibid., p. 287. 
purchase of supplies and forward these to a centrally located base. Here they would be collected and stored before being taken by the VOC's blue-water ships to Europe. In addition, supplies of food and other essentials, including gunpowder, could not be easily obtained or had to be produced on the spot. The proposed rendezvous was therefore also to act as a central location where ships would arrive in convoy, and for their onward journey disperse to other parts of Asia, before regrouping at the rendezvous and sailing to Europe.

The rendezvous would thus play a role similar to Goa for the Portuguese context, namely as a base for the supply of goods, food, men, as well as arms and ammunition. ${ }^{39}$ Matelieff lamented that, compared to the Iberians, the Dutch had to cope with much longer supply lines - indeed, they spanned almost half of the globe. The Dutch, moreover, had to bring their men from Europe, with the result that many arrived in Asia sick or incapacitated. The Portuguese and the Spanish, meanwhile, always seemed to have ample numbers of able fighting men at their disposal because they had bases at Goa and Manila and also maintained shorter supply lines.

While the purpose of establishing the rendezvous was evident, it was initially unclear which location would best serve this purpose. This rendezvous would need to be optimally located in order to facilitate the turnaround of vessels arriving from, or returning to, Europe. Based on the Portuguese experience, and in view of the interconnectivity of intra-Asian trading networks, Matelieff and the VOC directors first targeted a place somewhere in the Singapore and Melaka Straits region. Matelieff's seaborne assault on Melaka underscores that the Dutch had originally toyed with the idea of supplanting the Portuguese in key locations across the region, and that this would be preferably achieved by waging a relentless privateering campaign against the Iberian enemy. ${ }^{40}$ Once more experience had been collected in Southeast Asia, however, it became clear that a location in the Straits region especially Melaka - was not optimal. This is evident from a change in the language of letters and reports written by Matelieff between January and September 1608. After his arrival in Europe, the admiral shifted his attention away from the Malay Peninsula toward a location at or near the Sunda Strait. He found Banten not only problematic and politically unpredictable, but also an unhealthy place. Consequently, his choice now fell on Jayakerta, ${ }^{41}$ and the admiral reasoned thus: because the Melaka Strait extends from north to south and is affected by both the northeast and southwest monsoon seasons, it could not be easily reached all year round. By contrast, he explained, ships could enter and leave from the Sunda Strait at any time of the year because this maritime passage extends from west to east and is far shorter than the Melaka Strait. ${ }^{42}$ An additional consideration, moreover, was to optimise arrivals and departures to better exploit the trade winds and thus minimise the duration of the voyage between Europe and Asia.

39 Gaastra, The Dutch East India Company, pp. 39-40.

40 On the evolution of this strategy, see esp. P. Borschberg, 'From self-defence to an instrument of war: Dutch privateering around the Malay Peninsula in the early seventeenth century', Journal of Early Modern History 17, 1 (2013): 35-52. Concerning the broader strategy of the VOC in Asia during this period, see also Borschberg, 'Left holding the bag', pp. 89-120.

41 CMJ, pp. 84, 548.

42 Ibid., pp. 137-8. 
These considerations now require further unpacking. In ascertaining the best site for the future company rendezvous, Matelieff had shortlisted potential locations. They are, from north to south: Aceh, Melaka, the Hook of Berbukit (in the Johor River estuary near Singapore), Palembang, Banten and Jayakerta. The merits of each of these locations were discussed in some detail. This is admittedly not the occasion to delve into the advantages and disadvantages of the different locations, as this is the topic of a separate study ${ }^{43}$ Suffice it to note here that each site was duly scrutinised and weighed for its ease of access, position within the regional trading networks, as well as for its geo-strategic location. However, some additional considerations are well worth exploring.

The first concerns the broader geo-strategic significance of the regions surrounding the Singapore Strait and Johor River estuary. As transpires from Matelieff's memorials the geo-strategic significance of Singapore and its immediate surroundings were clearly recognised in Europe. It would appear that the Dutch (not unlike their Iberian counterparts) were contemplating the construction of at least one fortification somewhere around the Johor River estuary, and that would have doubtlessly included a site on Singapore or at another location nearby such as on Bintan or Karimun. It is known from a brief testimony by the former VOC factor in Johor that the Dutch were specifically eyeing the northwestern tip of present-day Sentosa where the British would later build Fort Siloso. ${ }^{44}$ This and nearby locations were deemed feasible at a time when the VOC still weighed the Singapore and Melaka Straits region as a possible choice for its Asian rendezvous. Earlier the directors had hoped to pluck Melaka from the Portuguese; but when this could not be achieved with Matelieff's seaborne attack on the port-colony in 1606, they began to explore more alternatives. Their attention now focused on another location nearby: the Johor River estuary. At the time of finalising the commission for the first Governor-General Pieter Both in the last weeks of 1609, the VOC directors still regarded Johor as a potential site for the company's rendezvous. ${ }^{45}$ By that stage, however, Matelieff had already set his eyes on a different region altogether. In a letter to Hugo Grotius penned in August 1610, the admiral explained that the area around the Johor River estuary was not a suitable location after all:

It has come to my attention, however, that the Gentlemen Directors in their latest instruction to Governor-[General] Pieter Both have indicated the Hook of Johor to him as the place to keep his residence (as a consequence, that would become our

43 P. Borschberg, 'Rendezvous: Admiral Cornelis Matelieff, the VOC and the Company's search for a base in Asia, 1605-19', forthcoming.

44 On this proposal, and its similarities with later plans put forward by Jacques de Coutre for the Iberian side, see, Admiral Matelieff's Singapore and Johor, 1606-1616, ed. P. Borschberg (Singapore: NUS Press, 2016), pp. 37-41. Concerning other security projects in and around the Straits around this time, see also Borschberg, 'Portuguese, Spanish and Dutch plans', Archipel 63, 2 (2003): 55-88.

45 Transcripts of the governor-general's first commission are found in Nederlandsch-Indisch Plakaatboek, 1602-1811, 17 vols., ed. J.A. van der Chijs (Batavia: Landsdrukkerij; The Hague: Martinus Nijhoff, 1885-1900), I, p. 8. The relevant instruction is found in art. 11 of the commission. De Both was to weigh 'at which location you want to establish yourself for the time being, be it on Banten, Johor or elsewhere'. Another copy of the Dutch text is in P.J.A.N. van Rietbergen, De Eerste Landvoogd Pieter Both (1568-1615): Gouverneur-Generaal van Nederlandsch-Indië, 2 vols. (Zutphen: Walberg Pers, 1987). 
rendezvous). I then did not think it necessary to write to you against it, since it was sufficiently rebutted in my previous writings, before that instruction had been written. Moreover, the Gentlemen Directors have been informed with the latest arriving ships that the king of Johor is completely opposed to creating a fortress in his country, so that need will make us understand what we cannot understand by reason. ${ }^{46}$

... [T] he rendezvous at Johor is unsuitable, because one cannot reach it at every time of the year. It is also unsuitable to navigate and sail to all locations, and then there is the jealousy of the aforementioned king [of Johor] who does not want to concede us a fortress there, as I and Pieter Willemsz. [Verhoeff] after me have found out by experience. ${ }^{47}$

This letter to Grotius is a valuable testimony for the history of Singapore in two respects: first, it shows that Singapore Island and the lands nearby had popped up on the proverbial radar screen of the early European colonial powers. After mature deliberation, however, the directors decided against establishing the VOC's principal Asian base here or at any other location nearby. Second, the decision not to establish a rendezvous near Singapore and the Johor River estuary also marked a permanent shift of attention away from Singapore and the Malay Peninsula. Thereafter, the Gentlemen Seventeen would focus - as Matelieff already did — on the Sunda Strait and northwestern Java. Two potential locations were now being seriously considered for the rendezvous: Banten and Jayakerta. With reference to the former, Matelieff observed:

The city of Banten, albeit well-situated, is not only very unwholesome, but also has a very young king - fourteen or fifteen years old - who is impossible to negotiate with; moreover, his council is so divided by factionalism that one cannot accomplish anything. ${ }^{48}$

The admiral's choice thus fell on an alternative site nearby:

My best advice would be, therefore, that we negotiate with the king of Jayakerta, so that we can build a fortress either in his city or at the aforementioned freshwater river [at Tanjung Burung]; the Sunda Strait can be sailed in every season, either to Banten or to Jayakerta, if one has rounded the Cape of Good Hope and one does not have to endure the monsoon. ${ }^{49}$

Matelieff was not alone in expressing such concerns. In their instructions to Pieter Both, the Gentlemen Seventeen thought it 'very advisable to enter into closer communication and alliance with the king of Jayakerta, ${ }^{50}$ to wit: to desire of him a suitable place to build a fort there'. This would 'serve to Our satisfaction as a rendezvous for the whole of the Indian navigation and of Our ships ...'. ${ }^{51}$ In his report to the

46 CMJ, p. 346.

47 Ibid., p. 348. See also the petition or remonstrance of Admiral Verhoeff and his brede raad (broad council) to Raja Bongsu of January 1609 in Admiral Matelieff's Singapore, pp. 177-88, and the Raja's reply, ibid., pp. 189-94. For the broader context of this request, see also Borschberg, Singapore and Melaka Straits, pp. 122-6.

48 CMJ, pp. 255-6.

49 CMJ, p. 256.

50 The ruler of Jayakerta was a pangeran and was technically loyal to and a tributary of the ruler of Banten. The Dutch described him as a 'vassal' of Banten.

51 Chijs, Nederlandsch-Indisch Placaatboek, I, p. 14, art. 23. 
directors dated 18 July 1616, Governor-General Laurens Reael, writing from Ternate, concurred with Matelieff and other VOC fleet commanders and highlighted that the Sunda Strait was the most suitable location for the company's Asian rendezvous.

This shift to a location south of the Malay Peninsula marked an important decision not only for the VOC, but it also shifted the focus of Dutch commercial and territorial expansion for the rest of the seventeenth century - and beyond.

\section{Agency of the Malay rulers}

What insights can be gained about the nature and dynamics of trade across the Southeast Asian region? This section will work in concentric circles, starting with the broader, overarching considerations of trade, diplomacy and international law and end with some observations on the inner workings of Johor.

Historians of the British Empire and Malay Archipelago researching the nineteenth and to an extent also the twentieth centuries are accustomed to thinking of Malay rulers as largely passive and responding to European initiatives. Colonial records broadly emphasise European ideas and actions and juxtapose these to responses of local Southeast Asian rulers, thus downplaying the agency of these local rulers. This problem has troubled scholars studying colonial materials on Southeast Asia. ${ }^{52}$ Researchers today who regularly engage with sources of the nineteenth and twentieth centuries lament how Southeast Asian rulers (and their subjects) are seen to reluctantly respond to the superior military might and commercial prowess of the European powers. One outcome of these supposed European initiatives was the imposition of unequal treaties that blatantly favoured European signatories, their agents, or their proxies.

Source materials from the earlier phase of European engagement with Southeast Asia paint a decidedly mixed picture. The language encountered in sources of the late sixteenth and early seventeenth centuries offers a sharp contrast to the tone of European sources from the nineteenth and early twentieth centuries. Matelieff's memorials show that the local rulers exercised agency independently, and the initiative was often not taken by the Europeans, but rather by the Asian rulers. For example, the king of Siam co-opted the Dutch by inviting them to join a future tributary mission to the Chinese imperial court. ${ }^{53}$ The ruler of Banten is said to have attempted to co-opt the Dutch (and even the English) in his war against Palembang; Johor sought to entice the Dutch to lend military assistance in its conflicts with Portuguese Melaka, Aceh, and Patani. ${ }^{54}$

The agency of the Southeast Asian rulers, moreover, is also evident from the way they negotiated their treaties or monitored the observance of their agreements with the Dutch. A classic example to this effect is the recorded conversation between Raja Bongsu and Matelieff aboard the admiral's flagship in May 1606. Raja Bongsu reminded Matelieff that it was he who had first solicited the assistance of the Dutch against Portuguese Melaka. Raja Bongsu also challenged the terms of the draft treaty during his negotiations with Matelieff. The admiral had proposed that

52 See for example, Anthony C. Milner, 'Colonial records history: British Malaya', Modern Asian Studies 21, 4 (1987): 773-92.

53 Borschberg, 'Cornelis Matelieff, Hugo Grotius and the King of Siam', forthcoming.

54 CMJ, pp. 274, 441-5. 
the city of Melaka be retained by the VOC as a reward for its role as a strategic partner and as war booty, and the raja eventually had to give in to this principal concession after being promised all the surrounding land. ${ }^{55}$ Following the failed siege of Melaka in 1606, however, Raja Bongsu (with the cooperation of the Johor bendahara [leading minister], Paduka Raja Tun Seri Lanang) again seized the initiative in September that year to forge a second treaty with the Dutch. The objective of this second treaty was to tie the fortunes of the VOC closer to Johor, and in the view of the raja and the bendahara, this could be best achieved by ceding a place to the Dutch where they could construct warehouses and residences. ${ }^{56}$ Admiral Pieter Willemsz. Verhoeff who was the next fleet commander to arrive in Johor during the opening weeks of 1609, sought to tinker with Dutch-Johor treaty of September 1606 and arm-twist Raja Bongsu into granting permission for the construction of a fort in Johor. ${ }^{57}$ In fact, Verhoeff's request to build a Dutch fort angered Raja Bongsu so much that the latter penned a letter of complaint to Verhoeff's political superiors in Europe - the stadtholder and the States-General - insisting that this was a violation of the terms spelled out in his Malay copy of the September 1606 treaty signed with Matelieff. ${ }^{58}$ The raja's diplomatic feathers were also ruffled by the negotiations that had been taking place in Europe for a truce between the Dutch Republic and Spain, which, due to a personal and dynastic union at the time, would also extend to the Portuguese. Raja Bongsu evidently thought that the Dutch had not lived up to an earlier agreement signed in May 1606, which stated in article 10 that before peace could be made with the Iberians, the consent of the counter-party was necessary. During the negotiations for the Twelve Years Truce (1609-21), the Dutch had never sought Johor's consent, as was expressly required. ${ }^{59}$

Beyond diplomacy and treaty-making, there were also some key commercial issues raised in Matelieff's letters and memorials. In a letter addressed to the Gentlemen Seventeen penned in June 1607, he observed that most of this commerce was transacted by barter and not in cash. Specifically, textiles from Cambay, the Coromandel Coast, or Bengal were exchanged for precious woods, spices, medicinal produce, or gemstones from insular and mainland Southeast Asia. Just how this barter trade worked and how the commodities reached their destination was something another author from this period, the Flemish-born merchant and gem dealer Jacques de Coutre, addressed in more detail. ${ }^{60}$

Of special interest are Matelieff's views on the trade in raw diamonds from southwestern Borneo. His concerns reflect some of the basic problems faced by the early VOC: the impact of political instability on the company's operations as well as the personal security of company employees in such disturbed areas. Add to this the potential interference by greedy and jealous local rulers. Because of the large sums

55 Ibid., pp. 154-60; Admiral Matelieff's Singapore, pp. 95-103.

56 CMJ, p. 160; Admiral Matelieff's Singapore, pp. 110-12.

57 See Margot E. van Opstall, ed., De reis van de vloot van Pieter Willemszoon Verhoeff naar Azië, 16071612, 2 vols. (The Hague: Martinus Nijhoff, 1972), I, p. 186.

58 See the letter by King Ala'udin and Raja Bongsu dated 8 Dec. 1609, pp. 449-50.

59 CMJ, p. 159.

60 See The memoirs and memorials of Jacques de Coutre: Security, trade and society in 17th century Southeast Asia, ed. P. Borschberg, trans. Roopanjali Roy (Singapore: NUS Press, 2014). 
involved in the trade of a compact, high-value commodity like diamonds, the admiral cautioned against letting company factors and clerks work with minimal or no supervision. While certainly profitable, the diamond trade was also beset with pitfalls. The VOC needed to deploy staff in the diamond trading centres of Borneo and Johor who were sufficiently trained and astute. The admiral underscored that Southeast Asian princes (or members of their extended family) were, as a rule, the largest merchants in their own polities. With reference to the Borneo diamond trade, the following considerations had to be taken into account: Since Sambas was claimed by Matelieff to have been a personal fiefdom of Raja Bongsu of Johor, any activity involving the trade in raw diamonds here would require his consent and his fullest cooperation. ${ }^{61}$ However, if fat profits could be reaped in the Borneo diamond trade, the raja was going to do that himself, leaving the VOC with proverbial slim pickings. ${ }^{62}$

\section{Banten, Ternate and Champa}

From among the different polities discussed by Matelieff in his memorials and letters, four are chosen for further investigation in the context of this article: Banten, Ternate, Champa, and Johor.

With reference to Banten, the documents evidence that the kingdom of Banten was ruled by an adolescent monarch. His uncle, who acted as regent, controlled him. The pangeran dominated trade in and with the city, and, responding to their pressure, official restrictions were imposed on European traders conducting business in Banten. In the words of the Dutch librarian and historian Pieter Anton Tiele, these pangerans behaved like little more than roofridders (robber barons). ${ }^{63}$ In a move to clip the power of Pangeran Arja Mandalika, the bendahara of Banten co-opted Jayakerta's military assistance, but he failed to achieve his main objective. ${ }^{64}$

At the time of Matelieff's first visit to the port city in 1607, Banten was waging a war with Palembang. Bantenese officials hoped to elicit Dutch support in this war by persuading the VOC to place some ships at their disposal. The admiral, however, advised caution in handling this and similar requests:

The king of Banten in his letters to the king of Holland ${ }^{65}$ is requesting two yachts to be at his disposal for two months in order to subdue the city of Palembang. In as far as we want to keep the peace with him, we will have to do this for him as soon as possible, or we will always quarrel with him at Banten. Things could go badly for our people

61 Concerning Johor's relations with Sambas, see J.H. Walker, 'From Po-li to Raja Brook: Culture, power and the contest for Sarawak', Journal of Borneo-Kalimantan 2, 2 (2016): 10-11, where he doubts the accuracy of Matelieff's judgement.

62 CMJ, pp. 295, 297.

63 Ibid., p. 82.

64 Tiele, 'De Europeërs in den Maleischen Archipel', pt VII, p. 67.

65 Holland was not a separate kingdom but a province within a federal republic generally referred to at the time as the United Provinces. The expression was used early on in the VOC's diplomatic correspondence with Asian rulers and refers to the States-General of the United Provinces, the stadtholder, or both. For an additional explanation see CMJ, pp. 488-9, and also P. Borschberg, 'Lost in translation? Property, Republican liberty and sovereignty in the languages of early modern diplomacy with Southeast Asia (late sixteenth and early seventeenth centuries)', in Globale Verflechtungen - Europa neu denken, ed. Susan Richter (Heidelberg: Heidelberg University Publishing, 2017), forthcoming. 
there in the end, if the States-General or the Company do not fulfil his wish as soon as possible. ${ }^{66}$

Attention now shifts eastward to the Spice Islands - the Banda and Maluku groups - both of which were hotspots in the Dutch conflict with the Iberian powers. Ternate was described as a sprawling polity covering many islands in the eastern Indonesian Archipelago. Many of these islands counted among the most productive in the growth and harvest of cloves. Due to Ternate's long-standing rivalry with neighbouring Tidore (a conflict exacerbated by European intervention), clove production on the islands loyal to the rulers of Ternate and Tidore declined precipitously during the first two decades of the seventeenth century. ${ }^{67}$ A key development had been the Dutch attack on, and takeover of, the Portuguese fort Nossa Senhora da Anunciada (Our Lady of the Annunciation, renamed Fort Victoria by the Dutch) on the island of Ambon during the opening weeks of 1605. Dutch successes in gaining a foothold in Maluku, and the eastern archipelago in general, evoked an armed response from Manila in the same year. In this Spanish-led campaign, the king of Ternate as well as leading members of the court were apprehended and taken to Manila as prisoners of war. ${ }^{68}$ The adolescent Modafar succeeded as sultan, but not all of Ternate's nobles endorsed his succession, and support for Modafar on some of the clove-producing islands of Maluku appears to have been tenuous at best. ${ }^{69}$ Matelieff's arrival at Malayur, and his efforts to protect Ternate against attacks by Tidore (the latter supported by its Iberian allies) gave young Modafar the proverbial shot in the arm that he needed. It is difficult to ascertain the extent to which Matelieff's support helped legitimise this teenage monarch in the eyes of Ternate's elite and subjects. It is against this backdrop that one should understand the willingness of the new monarch and his councillors to enter into a treaty with Matelieff (signed on 26 May 1607) that secured Dutch military protection of Ternate in return for Ternate's exclusive delivery of cloves to the VOC at a fixed price. ${ }^{70}$ This treaty was the first delivery contract and arguably marked an initial step in fulfilling Matelieff's grand plan to monopolise the clove market.

The admiral's travelogue also grants some glimpses into what was happening in Champa at the time. Focused on the central southern regions of present-day Vietnam, Champa was a polity that was in a protracted state of decline and, at the time of Matelieff's visit, struggling for survival. It should be said that Matelieff did not visit the mainland, but rather called at an island located off the central coast of present-day Vietnam known from period cartography as Pulau Cecir (Cù Lao Thu). The Journael briefly touches on the visit to this island and recounts some of the conversations of the admiral with Champanese officials there. ${ }^{71}$

66 CMJ, pp. 274, 334.

67 The sultans of Tidore and Ternate ruled two neighbouring islands by these names, but also commanded over sprawling maritime polities that extended as far as New Guinea, Mindanao and Sulawesi. See also CMJ, pp. 583-4.

68 Ibid., pp. 82, 126.

69 Ibid., pp. 84, 421.

70 Ibid., p. 89, and art. 10 of the treaty, p. 423.

71 Ibid., pp. 91-2. 
The king of Champa had a notorious reputation among the Iberian powers, especially the Spanish in Manila, for raiding shipping along the coast. ${ }^{72} \mathrm{He}$ was also accused of reducing to slavery members of captured crews, among whom were also some Europeans. Matelieff learnt of the religious tensions that had emerged between members of the royal family, but especially also of the crown prince's inclinations toward Islam. It would appear that, while the king and leading nobles at court remained Hindus or Buddhists, those Champanese who were involved in sea-borne commerce, including the aforementioned officials on Pulau Cecir, were predominantly Muslims. In this vein, the Journael alludes to an alliance forged between Champa and the ruler of Johor around 1606. Because of this alliance, at the time of Matelieff's visit Portuguese traders had only recently stopped calling at Champanese ports to trade..$^{73}$

\section{Johor}

It is beyond doubt that the most detailed information about any Southeast Asian polity contained in the Journael as well as the memorials touch on the kingdom of Johor. The written testimonies grant insights into Johor's historical evolution since the early sixteenth century, the ambitions of its rulers to build on the legacy of the Melaka Sultanate, as well as the dynamics among the different factions at Johor's royal court. Importantly, the Journael offers the only surviving European eyewitness accounts of the capital Batu Sawar as well as of another settlement slightly downstream and located on the opposite bank of the Johor River known as Kota Seberang. ${ }^{74}$

The royal court was dominated by factions, which had emerged around the four surviving sons of the late Raja Ali Jalla bin Abdul Jalil who had passed away around 1597. As Malay sources inform, the royal succession had been engineered by the aforementioned bendahara, Tun Seri Lanang, who appears to have been responsible for creating, or at least exacerbating, a (pre-existing) division of power at the Batu Sawar court. ${ }^{75}$ The four sons of Raja Ali Jalla are described in the Journael. ${ }^{76}$ Raja

72 Seville, Archivo General de Indias, Filipinas, 6, R.7 N. 106, 'Información sobre actitud hostil del rey de Champa' dated 30 Sept. 1593; Filipinas, 19, R.4, N. 57, 'Carta de Luís Pérez Mariñas con relaciones de Cochinchina, Siam', dated 15 June 1603.

73 Tiele, 'De Europeërs in den Maleischen Archipel', pt VII, p. 73. See also broadly, P.Y. Manguin, 'Etudes Cam. L'introduction de l'Islam au Campa', Bulletin de l'École française de l'Extrême-Orient 66 (1979): 255-87; Danny Wong Tze Ken, 'Vietnam-Champa relations and the Malay-Islam regional network in the 17th to 19th centuries', Kyoto Review 5 (2004), https://kyotoreview.org/issue-5/vietnamchampa-relations-and-the-malay-islam-regional-network-in-the-17th-19th-centuries/ (last accessed 29 June 2017).

74 See also P. Borschberg, Hugo Grotius, the Portuguese and free trade in the East Indies (Singapore: NUS Press; Leiden: KITLV, 2011).

75 This is intimated in the final chapter (34) or appendix to the Sejarah Melayu. See W. Shellabear, ed., Sejarah Melayu (The Malay Annals) (Singapore: Malaya Publishing House, 1961), p. 323; and A. Samad Ahmad, ed., Sulalatus Salatin (Sejarah Melayu) (Kuala Lumpur: Dewan Bahasa dan Pustaka, 1986), p. 311.

76 The account later provided by the Dutch cleric François Valentyn follows the Journael ende Verhael of Matelieff's voyage. His opinion of Ala'udin is found in the English translation of the Dutch original by D.F.A. Hervey, 'Valentyn's account of Malacca', Journal of the Straits Branch of the Royal Asiatic Society 16 (1885): 119-38; see similarly Richard O. Winstedt, A history of Johore (Kuala Lumpur: MBRAS, 1979), p. 25. 
Ali's successor as yang di pertuan agung (broadly: king), Ala'udin Ri'ayat Shah III, is painted here as a drunkard and womaniser who seemed to care little about the fate of his kingdom or affairs of state in general. ${ }^{77}$ With hindsight, this might be an exaggeration, but this Johor ruler doubtless left a very negative impression on Matelieff and also on subsequent VOC officers who would visit the Johor royal court until the end of his rule around 1613. That negative impression, the Journael informs, had been conveyed to the Dutch by the Johorean emissaries returning from the Dutch Republic aboard Matelieff's flagship in 1605-06.

The second son was Raja Siak, also known from the Sejarah Melayu as Raja Hasan. He does not seem to have spent much time at the court, and it remains uncertain whether Matelieff had even met him in person. Raja Siak has been portrayed as a scheming individual who did a brisk trade with the Portuguese in jungle produce like camphor and porcupine bezoars - an observation that is incidentally echoed in Jacques de Coutre's writings. ${ }^{78}$

The third son, Raja Laut, was another individual of considerable notoriety who is described as a drunkard, womaniser, and a manslayer. The documents included in this collection have in fact very little to say about this individual, and there is no mention of him by this (or any similar title) in the Sejarah Melayu. The Dutch academic Pieter Gerritsz. Rouffaer surmised that the Raja Laut may in fact have been the laksamana, a type of fleet commander and officer in charge of receiving overseas merchants. ${ }^{79}$ Resorting to other Malay-language materials, this individual also may have been the Raja Selat ('King of the Strait'), who traditionally resided on Singapore. He was the ketua orang laut, or the leader of the Orang Laut, a term that collectively refers to nomadic sea tribes who lived on their boats and moved around the islands of the Straits and the Riau Archipelago. ${ }^{80}$

Fourth and finally, we read of Raja Bongsu, and as the Malay nickname suggests he was the youngest of the princes. Known variously from European and Malay sources as Raja Seberang, Raja di Ilir, or Raja Abdullah, he is said to have yielded his succession in favour of his older half-brother Ala'udin in 1597. Matelieff had nothing but praise for this young prince whom he regards together with Ala'udin as one of the co-rulers of Johor. Raja Bongsu was seen as someone who was able and motivated. As co-ruler, he was principally involved with foreign (trade) and alliance policies, and in exercising these duties first sided with the Dutch during the visit of Admiral Jacob van Heemskerck in Johor in 1602-03. Raja Bongsu, moreover, is credited with having masterminded the first Johor diplomatic mission to the Dutch Republic whose members sailed to Europe aboard the ships of Van Heemskerck in $1603 .{ }^{81}$ The surviving members of the mission, including Encik Kamar, returned to Johor with Matelieff's fleet in $1605-06 .^{82}$

77 Hervey, 'Valentyn's account of Malacca', pp. 134-5.

78 CMJ, pp. 153, 194n278; Borschberg, Admiral Matelieffs Singapore, pp. 93-4.

79 Gerrit Pietersz Rouffaer, 'Was Malaka Emporium vóór 1400 A.D. genaamd Malajoer? En waar lag Woerawari, Ma-Hasin, Langka, Batoesawar?', Bijdragen van het Koninklijk Instituut voor Taal-, Landen Volkenkunde 77 (1921): 1-174, 359-604.

80 Borschberg, Admiral Matelieff's Singapore, pp. 21-5, 78, 95.

$81 C M J$, p. 54.

82 CMJ, p. 56; Borschberg, Singapore and Melaka Straits, p. 122; Borschberg, Hugo Grotius, the Portuguese and free trade, p. 364. 
The discussion of key personalities would not be complete without also saying a few words about Johor's bendahara. As has been mentioned earlier, this was Tun Seri Lanang, who is better known today for his role in shaping Sululatus Salatin (Sejarah Melayu or Malay Annals) in its present form. ${ }^{83} \mathrm{He}$ did not leave a positive impression with Matelieff. The Journael recalls the moment when the bendahara and Matelieff were discussing the planned Johor-Dutch military campaign against Portuguese Melaka:

The bendahara even had the audacity to say to the admiral, in the king's presence while he was in his council, that our people had conquered Ternate and Ambon without the inhabitants' help, and therefore they ought to do so in this case as well; for he had not come to fight, but to watch the fight. To which the admiral replied: 'I have come here as a servant to the king, the Yang di Pertuan, whose war this was. If you do not wish to be his servant, nor do him any service, you can say so; and if king, Yang di Pertuan, commands me to, I will make such people leave here.' When the king heard this, he was annoyed with the bendahara, and many noblemen were very pleased that the admiral spoke to him like that, since he was an arrogant fool and a rude beast, who seemed to be more on the Portuguese than on the Dutch side. His position was that of the king's governor. ${ }^{84}$

This passage casts the bendahara in a decisively negative light. Elsewhere in Matelieff's manuscripts, it is claimed that the bendahara had sided with the Portuguese, but admittedly, no evidence is provided to substantiate this assertion.

Moving away from the four brothers, the bendahara, and life at the royal court, one finds a brief description of the city of Batu Sawar as well as the nearby settlement Kota Seberang. The latter is said to have been a personal fief of Raja Bongsu. The Journael states:

The city of Batu Sawar lies on the Johor River, about five or six miles from the sea. ${ }^{85}$ It is a very beautiful river, broad and deep, subject to ebb and flood up to the city, but before the city it is fresh. Most of the land is lowland. The people mostly live along the river. The houses are built on poles. There are two places which are called fortress; one of them is Batu Sawar, the other lies on the opposite river bank and is called Kota Seberang. Batu Sawar is about 1,300 treden in circumference, ${ }^{86}$ built as a square with high palisades 40 feet tall and set closely together; it has some fortifications to the side, but not well made. It lies on a flat field close to the river. The nearest hills are a quarter of a mile away from [the city]. One could easily make the river surround it. Inside, the city is closely packed with straw houses, apart from those belonging to the king and some noblemen, which are made of wood. In Batu Sawar and Kota Seberang combined, it is estimated that there are no less than 3,000 to 4,000 fighting men, but most of the people live outside the fortress. ... Kota Seberang may be some 400 or

83 Winstedt, History of Johore, pp. 33-4.

84 CMJ, p. 168. See also Admiral Matelieff's Singapore, pp. 81-3.

85 This appears to be a reference to the Dutch sea mile of $7.4 \mathrm{~km}$; or alternatively also the Dutch mile that, depending on location, ranges from $3.86-5.5 \mathrm{~km}$.

86 The circumference amounts to about $975 \mathrm{~m}$. 
500 treden in circumference and is square as well. ${ }^{87}$ Not many people live there, and the riverside where they live is also defended by palisades. ${ }^{88}$

Surprisingly, Matelieff's documentation fails to address commerce in and around the Johor capital. From other period sources, however, it is known that Johor served as an important commercial node that attracted many ships to trade and itself acted as a home base for many merchants of undisclosed origin. ${ }^{89}$ What Matelieff does mention, however, is that Batu Sawar relied heavily on food imports - as was indeed the case with other important urban centres of peninsular and insular Southeast Asia, such as Melaka. This dependence on food from outside sources rendered the upstream towns of the Johor River vulnerable to blockades by the Portuguese or other hostile parties. The admiral explained the situation in these words:

All the land belongs to the king and is hardly valued, so that whoever asks it of him can receive enough land. It appears to be very fertile nonetheless, for it is full of trees and the grass reaches a man's belly. But the land is not cultivated, for if [the locals] turned to agriculture they would have everything in abundance, whereas now they are in want of many things. ${ }^{90}$

These observations on the Johor capital Batu Sawar close the discussions on a set of concentric themes that started with the bigger geo-strategic deliberations, the proposed monopolisation of the trade in nutmeg, mace and cloves, as well as specific observations on different polities around insular and peninsular Southeast Asia. Among these Johor and the Johor River in general stand out for the detail in which they are described.

\section{Concluding observations}

What does this all boil down to? Of what value are Admiral Matelieff's writings to the present-day student, reader and researcher? The bottom line is this: The surviving documents touching on the voyage of Matelieff were written for different objectives and bore different agendas. The Journael extolled the victory of Matelieff and the early VOC over the far more entrenched Iberian powers of Spain and Portugal in the East Indies. By contrast, the memorials identified problems and suggested possible solutions that the VOC was facing in Asia. While the documents certainly focus on the Europeans, their enemies, their problems and their exploits in Asia, the materials nevertheless contain glimpses into Southeast Asian societies during the early modern period that have long been eclipsed by imperialism, colonialism and modernisation.

The value of Matelieff's writings to readers and researchers of Southeast Asia is clear: the texts shed light on trade, trading networks, material culture, consumption, international diplomacy, and war in early modern Southeast Asia. In an era where European powers did not enjoy a wide technological lead over their Asian

87 The circumference amounts to about $225-300 \mathrm{~m}$.

88 CMJ, p. 191.

89 P. Borschberg, 'Batu Sawar Johor: A regional centre of trade in the early seventeenth century', in Early modern Southeast Asia, 1350-1800, ed. Ooi Keat Gin and Hoang Anh Tuan (London: Routledge, 2016), pp. 136-53.

90 CMJ, pp. 191-2; Admiral Matelieff's Singapore, p. 109. 
counterparts, international affairs were conducted by the Europeans in a way that nominally at least placed the Asian rulers as sovereigns on an equal footing with their European counterparts. What strikes today's reader of Matelieff's writing is the agency and initiative demonstrated by the Southeast Asian rulers. They are not merely responding to European promptings and initiatives, but are diplomatic forces to be reckoned with. One gains a sense that, during these early years of VOC presence in Southeast Asia, the Dutch were feeling their way around an entirely new setting. They are not only casting a wary eye on their far more established Iberian competitors, they are also finding themselves (sometimes unwillingly) drawn into regional power games and conflicts. For all the candid, sometimes condescending observations that were put to paper, Matelieff's writings offer important snapshots of a world that was about to face profound change. The VOC was not yet that mighty and successful survivor among the chartered companies. It was in Matelieff's time still in its infancy, trying to balance its new dual role as a trading organisation and as an instrument of war. As the directors and admirals fumbled in coming to grips with a trading and political environment so different from their own in Europe, each major policy decision in these early years was to significantly impact the Dutch company, and generally also its economic and political environment in Southeast Asia. 